\title{
Factor Analysis and Empirical Research on Regional Logistics Demand in Jiangxi Province
}

\author{
Yongfei XU \\ Changzhou Textile Garment Institute, Changzhou 213164, China
}

\begin{abstract}
This article analyzed the economic position of Jiangxi province from the aspects of gross economic value, industry structure and investment in fixed assets etc. It also explained the development state of logistics in terms of the infrastructure equipment, the status quo of logistics development as well as logistics corporation development. With the 2000-2012 annual data of gross domestic product; total output value of primary, secondary and tertiary industry; total volume of retail sales; total foreign trade value; fixedassets investment; income per capita; cargo and freights turnover; etc, we conduct the factor analysis of regional logistics demand in Jiangxi by using the multivariate regression model and measurement stepwise regression method. The results showed that: firstly, the total volume of retail sales of social consumer products increased by ten million Yuan will lead to an increase of 92.35333 thousand tons of cargo volume. The fixed-assets investment of the entire society increased by 10 million Yuan, will lead to a raise of 72.02902 thousand tons of fright turnover. Secondly, with a determination coefficient R2 $=0.9754$, it is believed that the total volume of retail sales and total fixed-assets investment of entire society have $97.54 \%$ explaining power on cargo volume, which indicating a well-fitted model.
\end{abstract}

KEYWORDS: Jiangxi Province; regional logistics; demand forecast; influencing factors; empirical research.

\section{INTRODUCTION}

A scientific and reasonable logistics planning requires proper logistics demand analysis. The success of logistics development planning as well as the speed and quality of economic development are all related to the correctness of logistics demand analysis. The logistics demand analysis can maintain the regional logistics in high effectiveness and efficiency, in the other words, it is able to balance the regional demand and supply and contribute to a well development. A scientific logistics demand analysis and forecast together with good logistics demand control lay down an essential foundation for scientific strategy planning in logistics development and feasible market open-up strategy. Meanwhile, it can also be regard as a reference in making the macro industrial economic policies, in a way of helping to avoid the duplicated construction, to guide the investment, and to prevent the logistics infrastructure construction and services from rushing forward.

As a part of the central rise strategy of China, Jiangxi province located right near Wuhan-the industrial powerhouse, within city Wuhan's economic radiation circle, and process rich resources in minerals, traveling, and culture. The opening economic development model has brought chances as well as challenges to Jiangxi. To ensure sustainable economic development, and enhance the developing pace of logistics industry, the importance of logistics demand analysis is pretty obvious and noticeable.

\section{RESEARCH STATUS}

\subsection{Domestic Research Status}

The logistics industry in China is still in its initial stage of development, the focus of logistics demand analysis is mainly on the regional urban logistics demand and the development is slower than the developed countries like US. Although certain research results have been achieved in this area, the logistics industry is still in its beginning stage, processing slowly and lacking of systematical development. Therefore has not yet brought enough attention of the people in academic fields and logistics fields. And there isn't enough emphasis on the research of logistic demand forecast either. $\mathrm{He}$ related research about logistics demand still got lot of space to be developed; therefore it is needed to 
increase the intensity of positive policies support in order to provide more encouragement.

\subsection{Oversea Research Status}

For those oversea European and American countries, the research of logistic demand started early. Not only did they emphasis on the research of logistics theory, but also had they made clear stipulation related to logistics in order to encourage and enhance the development of logistics industry. Moreover, they had set up an institutional system, which mainly focus on the research of predicting model in logistics demand forecasting and conduct the forecast by predicting the freight volume.

Bahram Adrangi, 2001, studied the service demand position of aviation industry in US with other researchers. According to his analysis on the monthly statistics of aviation, he believed that the aviation service in America performed a non-linear structure. Then he conducted the forecast by using GARCH model and came up with the conclusion that using GARCH model will help to obtain better result in forecasting the aviation services in US[1]. Donald J.Bowersox 1998, in his book "logistics management: Supply chain process integration", he explained the application of logistics planning technology in choosing address, inventory and transportation field and divided the logistics demand forecasting into three technological categories[2]. In 2003, since there was related legal and policy support, Gaudette, Alcorn and Mangan analyzed the basic elements of establishing compensation prediction model and the functions of Air Force inventory management published in their journal.
They also compared and contrasted their model to the raw material demand planning model[3]. 2001, according to logistics demand data in India in 1960s, Mudit Kulshreshtha derived the relationship among demand of goods by using the time series model and conducted the dynamic econometric sequence modeling. They forecasted the data using VAR model, and the result shown that high flexible GDP and low flexible price, which included real transportation price, would cast a great impact in economic production[4].

With above observation, it seems that the developed countries and regions emphasis much on researches of logistics demand forecasting. Not only in research of theory, but also emphasis on legal support. Compare with that, we still have certain gap with those developed countries in terms of research time and research achievement.

\section{VARIABLES, DATA AND MODEL}

\subsection{Variables and data}

According to the literature review, the data is collected from the China annual statistics review. Figure 1 shows the various index data in Jiangxi Province. $\mathrm{Y}$ is indicating of cargo, $\mathrm{F}$ is indicating freight turnover, $\mathrm{x} 1$ is GDP value, $\mathrm{x} 2$ is the output value for primary industry, $\mathrm{x} 3$ is the output value for secondary industry, $\mathrm{x} 4$ is output value for the tertiary industry, $x 5$ is the total volume of retail sales of social consumer goods, $\mathrm{x} 6$ is the total volume of international trade, $x 7$ is the total fixed-assets investment, $x 8$ is the income per capita

Table 1-1 Index statistics

\begin{tabular}{|c|c|c|c|c|c|c|c|}
\hline Year & 2000 & 2001 & 2002 & 2003 & 2004 & 2005 & 2006 \\
\hline Cargo(TTT)Y & 23502 & 24174 & 26089 & 27709 & 31924 & 33996 & 37517 \\
\hline freight turnover(HMT.KM)F & 746.93 & 653.6 & 717.6 & 768.6 & 870.1 & 885.2 & 947.76 \\
\hline GDP(HMCNY)X1 & 2003.07 & 2175.68 & 2450.48 & 2807.41 & 3456.70 & 4056.76 & 4820.53 \\
\hline $\begin{array}{l}\text { output value for primary industry (HMCNY) } \\
\mathrm{X} 2\end{array}$ & 484.74 & 506.93 & 536.66 & 558.67 & 705.17 & 726.16 & 809.85 \\
\hline $\begin{array}{l}\text { output value for secondary industry } \\
(\mathrm{HMCNY}) \mathrm{X} 3\end{array}$ & 701.07 & 785.42 & 938.53 & 1218.42 & 1576.26 & 1918.85 & 2419.91 \\
\hline $\begin{array}{l}\text { output value for the tertiary industry } \\
\text { (HMCNY) X4 }\end{array}$ & 817.25 & 883.33 & 970.39 & 1044.36 & 1227.13 & 1411.75 & 1614.88 \\
\hline $\begin{array}{l}\text { total volume of retail sales of social consumer } \\
\text { goods (HMCNY) X5 }\end{array}$ & 704.9 & 763.3 & 832.7 & 923.2 & 1059.9 & 1244.9 & 1448.2 \\
\hline $\begin{array}{l}\text { total volume of international trade (HMUSD) } \\
\text { X6 }\end{array}$ & 20.52 & 18.04 & 19.97 & 29.57 & 48.19 & 49.59 & 72.52 \\
\hline total fixed-assets investment, (HMCNY) X7 & 516.08 & 415.42 & 611.55 & 975.4 & 1488.39 & 1933.93 & 2377.41 \\
\hline income per capita (CNY) X8 & 4851 & 5221 & 5829 & 6624 & 8097 & 9440 & 11145 \\
\hline
\end{tabular}


Table 1-2 Index statistics

\begin{tabular}{|c|c|c|c|c|c|c|}
\hline Year & 2007 & 2008 & 2009 & 2010 & 2011 & 2012 \\
\hline Cargo(TTT)Y & 40921 & 80932 & 86057 & 100635 & 111851 & 127196 \\
\hline freight turnover(HMT.KM)F & 1026.92 & 2289.85 & 2350.91 & 2720 & 2985.10 & 3433.5 \\
\hline GDP(HMCNY)X1 & 5800.25 & 6971.05 & 7655.18 & 9451.26 & 11702.82 & 12948.88 \\
\hline output value for primary industry (HMCNY) X2 & 951.24 & 1143.25 & 1102.35 & 1209.76 & 1378.47 & 1515.02 \\
\hline output value for secondary industry (HMCNY) X3 & 2975.53 & 3673.74 & 3919.45 & 3188.92 & 6324.75 & 6904.60 \\
\hline output value for the tertiary industry (HMCNY) X4 & 1919.88 & 2356.21 & 2625.73 & 1044.36 & 1227.13 & 1411.75 \\
\hline $\begin{array}{l}\text { total volume of retail sales of social consumer } \\
\text { goods (HMCNY) X5 }\end{array}$ & 1718.9 & 2142 & 2484.4 & 2956.2 & 3485.1 & 4027.2 \\
\hline total volume of international trade (HMUSD) X6 & 103.13 & 150.07 & 138.31 & 209.53 & 279.90 & 302.36 \\
\hline total fixed-assets investment, (HMCNY) X7 & 3300.10 & 4745.43 & 6642.37 & 8772.3 & 9089.77 & 11338.92 \\
\hline $\begin{array}{l}\text { income per capita } \\
\text { (CNY) X8 }\end{array}$ & 13322 & 15900 & 17185 & 21253 & 26150 & 28799 \\
\hline
\end{tabular}

\subsection{Model}

The econometric model includes one or more than one stochastic equations. It simply and effectively describes the quantitative characteristics of a real economic system and fully explains the variation of the quantitative track of the economic system. The most frequently used analyzing method in econometrics modeling is regression analysis method. We also construct the model using this method.

When using regression analysis method to construct model, we need to choose a variable from all the variables to be explained variable, which means dependent variable, and others are explanatory variables which is independent variables[5]. In regression model, we can divide the model into simple regression model, Bivariate regression model and multiple regression model according to the number of independent variables. And we can divide the model into linear regression and non-linear regression according to the correlation between independent variables and dependent variable.
When explained variable $\mathrm{Y}$ is affected by more than one explanatory variables $\mathrm{Xi}$ at the same time, with $\mathrm{Xi}(\mathrm{i}=1,2, \ldots, \mathrm{n})$ all are linear correlated, then we can construct multiple regression model, the model can be written as

$$
\mathrm{Y}=\mathrm{B}_{0}+\mathrm{B}_{1} \mathrm{X}_{1}+\mathrm{B}_{2} \mathrm{X}_{2}+\cdots+\mathrm{B}_{\mathrm{n}} \mathrm{X}_{\mathrm{n}}+\mathrm{U}
$$

$\mathrm{Y}$ is dependent variable, $\mathrm{Xi}(\mathrm{I}=1,2,3, \ldots, \mathrm{k})$ is independent variables. $B \mathrm{j}(\mathrm{j}=0,1,2, \ldots, \mathrm{k})$ is regression coefficient, $\mathrm{U}$ is the stochastic error (the other factors that will affect $\mathrm{Y}$ except $\mathrm{X}$ )

\section{EMPIRICAL ANALYSIS}

From the literature we know that, there is a strong correlation between each economic variable. In multiple regression analysis, it will cause a large bias if we do not remove the possible multicollinearity. Therefore we must conduct the multicollinearity test. First of all, we conduct the simple regression analysis on cargo and correlated economic variable, and the get the optimized R square (the maximum $\mathrm{R}$ square) of variable, shown in below table:

Table 2 R square between cargo, freight turnover and the variables

\begin{tabular}{|c|c|c|c|c|c|c|c|c|}
\hline $\mathrm{R}^{2}$ & $\mathrm{X} 1$ & $\mathrm{X} 2$ & $\mathrm{X} 3$ & $\mathrm{X} 4$ & $\mathrm{X} 5$ & $\mathrm{X} 6$ & $\mathrm{X} 7$ & $\mathrm{X} 8$ \\
\hline $\mathrm{Y}$ & 0.955818 & 0.936367 & 0.953159 & $\mathrm{O} 962409$ & 0.969962 & 0.955254 & 0.974679 & 0.954440 \\
\hline $\mathrm{F}$ & 0.934142 & 0.917942 & 0.931030 & 0.943026 & 0.951350 & 0.938720 & 0.959756 & 0.932557 \\
\hline
\end{tabular}

It can be obviously observed that when each explanatory variable is positive correlated to explained variables, the maximum $\mathrm{R}$ square for $\mathrm{Y}$ (cargo) and $\mathrm{F}$ (freight turnover) are all at $\mathrm{x} 7$ and that is the only figure exceeded 0.95 , which also meet the economic significance. Therefore, we choose $\mathrm{x} 7$ and continue to do the stepwise regression and multicollinearity test. Shown in table 3:

Table $3 \mathrm{R}$ square for Cargo, Freight turnover, total fixed-assets investment and other index

\begin{tabular}{|c|c|c|c|c|c|c|c|}
\hline $\mathrm{R}^{2}$ & $\mathrm{X} 7 / \mathrm{x} 1$ & $\mathrm{X} 7 / \mathrm{x} 2$ & $\mathrm{X} 7 / \mathrm{x} 3$ & $\mathrm{X} 7 / \mathrm{x} 4$ & $\mathrm{X} 7 / \mathrm{x} 5$ & $\mathrm{X} 7 / \mathrm{x} 6$ & $\mathrm{X} 7 / \mathrm{x} 8$ \\
\hline $\mathrm{Y}$ & 0.974795 & 0.976697 & $\mathrm{O} .974794$ & 0.974997 & 0.975462 & 0.976531 & 0.97479 \\
\hline $\mathrm{F}$ & 0.959938 & 0.96105 & 0.959945 & 0.959756 & 0.959839 & 0.961165 & 0.959946 \\
\hline
\end{tabular}


In table 3, there are two $\mathrm{R}$ square figures larger than 0.95 , stating significant. But in the perspective of economic significance, only $\times 7 / \times 5$ have positive coefficient with cargo value, and $\times 7 / \times 3$ have positive coefficient with freight turnover. And all of them is larger than the previous value with only fitting to $\mathrm{x} 7$. Therefore, we choose $x 7 / x 5$ and $Y, x 7 / x 3$ and $F$ to continue the stepwise regression process. Shown in table 4:

Table 4, R square for Cargo, Freight turnover and total fixed-assets investment and international trade volume and other index

\begin{tabular}{|c|l|l|l|l|l|l|}
\hline $\mathrm{R}^{2}$ & $\mathrm{X} 7 / \mathrm{x} 6 / \mathrm{x} 1$ & $\mathrm{X} 7 / \mathrm{x} 6 / \mathrm{x} 2$ & $\mathrm{X} 7 / \mathrm{x} 6 / \mathrm{x} 3$ & $\mathrm{X} 7 / \mathrm{x} 6 / \mathrm{x} 4$ & $\mathrm{X} 7 / \mathrm{x} 6 / \mathrm{x} 5$ & $\mathrm{X} 7 / \mathrm{x} 6 / \mathrm{x} 8$ \\
\hline $\mathrm{Y}$ & 0.978964 & 0.977211 & 0.978732 & 0.977920 & 0.976657 & 0.978954 \\
\hline $\mathrm{R}^{2}$ & $\mathrm{X} 7 / \mathrm{x} 4 / \mathrm{x} 1$ & $\mathrm{X} 7 / \mathrm{x} 4 / \mathrm{x} 2$ & $\mathrm{X} 7 / \mathrm{x} 4 / \mathrm{x} 3$ & $\mathrm{X} 7 / \mathrm{x} 4 / \mathrm{x} 5$ & $\mathrm{X} 7 / \mathrm{x} 4 / \mathrm{x} 6$ & $\mathrm{X} 7 / \mathrm{x} 4 / \mathrm{x} 8$ \\
\hline $\mathrm{F}$ & 0.975312 & 0.976817 & 0.975090 & 0.977128 & 0.977920 & 0.975259 \\
\hline
\end{tabular}

From table 4, we can see that $\mathrm{R}$ square has an increase, but the coefficient are all negative, which has no economic significance. Therefore, we can confirm that $\mathrm{Y}$ (cargo) have the optimized $\mathrm{R}$ square with $\mathrm{x} 7$ (total fixed-assets investment) and $\mathrm{x} 5$ (total volume of retail sales of social consumer goods) while $\mathrm{F}$ (Freight turnover) have the optimized $\mathrm{R}$ square with $\mathrm{x} 7$ (total fixed-assets investment) and $\mathrm{x} 3$ (total output of secondary industry). Then we can use Eviews to do related calculation. The results are as following:

Cargo: $Y=12057.21+9.235333 * x 5+7.202902 * x 7$

$$
\begin{array}{lcc}
\mathrm{Se}=(11027.13) & (16.34496) & (4.810925) \\
\mathrm{T}=(1.093414) & (0.565026) & (1.497197) \\
\mathrm{P}=(0.2999) & (0.5845) & (0.1652) \\
\mathrm{R}^{2}=0.975462 ; \mathrm{F}=198.7664 &
\end{array}
$$

Freight Turnover:

$\mathrm{F}=532.8941+0.041605^{*} \mathrm{x} 3+0.288646^{*} \mathrm{x} 7$

$$
\begin{array}{lcc}
\mathrm{se}=(169.0236) & (0.191648) & (0.107434) \\
\mathrm{T}=(3.152778) & (0.217090) & (2.686743) \\
\mathrm{P}=(0.0103) & (0.8325) & (0.0228) \\
\mathrm{R}^{2}=0.959945 ; \mathrm{F}=119.8269 &
\end{array}
$$

\section{CONCLUSION AND RECOMMENDATION}

Based on the 2000-2012 annual data of gross domestic product; total output value of primary, secondary and tertiary industry; total volume of retail sales; total foreign trade value; fixed-assets investment; income per capita; cargo and freights turnover of Jiangxi Province, using the multiple regression model and stepwise regression method to analyze the factors that affect logistics demand in Jiangxi, the result shows:

1) All the coefficient is positive, and the value meet economic significance, which indicating that the total volume of retail sales of social consumer products increased by ten million Yuan will lead to an increase of 92.35333 thousand tons of cargo volume. The fixed-assets investment of the entire society increased by 10 million Yuan, will lead to a raise of 72.02902 thousand tons of fright turnover.

2) With a determination coefficient $\mathrm{R} 2=0.9754$, it is believed that the total volume of retail sales and total fixed-assets investment of entire society have 97.54\% explaining power on cargo volume, which indicating a well-fitted model.

3) F-test(the variance test) result showed a 0.000 percent of significance, which indicate that the overall regression result is significant, the significance of explanatory variable, and $t$ value of constant term have passed the test.

4) From the logistics demands regression analysis we observed that total fixed-assets investment of the whole society is the common factor that affect both cargo and freight turnover in Jiangxi Province. Other than that, total volume of retail sales of social consumer goods has influence more on cargo, while the total output of secondary industry has more impact on freight turnover. Based on this, we can see there is need to adjust the industrial structure in Jiangxi, or the tertiary industry and international trading service need more development.

\section{REFERENCES}

[1] Bahram Adrangi, Arjun Chatrath, Kambiz Raffiee. The demand for US air transport service: a chaos and nonlinearity investigation. TransportationResearch.2001, 1(37): 337-353

[2] Donald J. Bauer Dsokas. Logistics Management: The process of supply chain integration. Beijing: Machinery Industry Press, 1998

[3] Kevin Gaudette, H.Kenneth Alcorn, Matthew Mangan. Reparability forecasting Model. Air Force of Logistics.2003, (4): 4-42

[4] Mudit Kulshreshtha, Aarnali Nag, Mukul Kulshrestha. A Multivariate Cointegrating Vector Auto-regressive Model of Freight Transport Demand: Evidencefrom Indian Railways. Transportation Research Part A, 2001, 29 45

[5] Li Zi-Nai, Fan Wen-Qing, Econometrics, 2nd Ed. Higher Education Press, Beijing, 2005 pp. 217- 241 